\title{
Genetic variability in three Amazon parrot species
}

\author{
Lopes, IF. ${ }^{\text {a }}$ Del Lama, MA. ${ }^{\text {a* }}$ and Del Lama, SN. ${ }^{\text {a }}$ \\ aDepartamento de Genética e Evolução, Universidade Federal de São Carlos - UFSCar, \\ Rodovia Washington Luiz, Km 235, CEP 13565-905, São Carlos, SP, Brazil \\ *e-mail: dsdl@power.ufscar.br \\ Received August 16, 2007 - Accepted October 5, 2007 - Distributed December 1, 2007
}

\begin{abstract}
Parrots of the genus Amazona are among the most threatened species of the Order Pscittaciformes. This work describes allozyme polymorphisms in three Amazon parrot species - the Blue-fronted Amazon (Amazona aestiva), the Orangewinged Amazon (Amazona amazonica), and the Festive Amazon (Amazona festiva) -, and provides useful data for the evaluation of their genetic variability. We electrophoretically analyzed blood samples from 68 wild-caught individuals, maintained in captivity in three Brazilian zoos. Eight of the ten studied enzyme loci exhibited polymorphism. Glucosephosphate isomerase ( $\mathrm{Gpi}$ ) proved to be a diagnostic locus for the identification of these Amazon species. The expected average heterozygosity of the Blue-fronted Amazon (0.060) differed significantly from the expected heterozygosities of the Orange-winged Amazon and the Festive Amazon (0.040 and 0.039, respectively). This result was discussed as a consequence of hybridization between two geographic A. aestiva subspecies, and alternatively as a particular trait of this species. Genetic variability of the Blue-fronted Amazon compared to birds in general is not low on a species-wide level, despite the fact that this parrot is one of the most illegally traded species. Allozyme analysis proved to be an useful tool in monitoring the genetic variation within the genus Amazona and can be applied in the management program of other threatened species of this genus.
\end{abstract}

Keywords: genetic variation, parrots, allozymes, illegal trade.

\section{Variabilidade genética em três espécies de papagaios do gênero Amazona}

\section{Resumo}

Papagaios do gênero Amazona estão entre as espécies mais ameaçadas da Ordem Psittaciformes. O presente trabalho descreve polimorfismos enzimáticos em três espécies de papagaios do gênero Amazona: o papagaio verdadeiro (Amazona aestiva), o papagaio do mangue (Amazona amazonica) e o papa-cacau (Amazona festiva). Estes dados foram utilizados para avaliação da variabilidade genética dessas espécies. Foram analisadas, através de eletroforese, amostras de sangue de 68 indivíduos capturados na natureza e mantidos em cativeiro em três zoológicos brasileiros. Oito dentre dez locos enzimáticos analisados exibiram polimorfismo. O loco da Glicose Fosfato Isomerase (Gpi) demonstrou ser um loco diagnóstico para a identificação dessas espécies de papagaios. A heterozigosidade média esperada para $A$. aestiva $(0,060)$ diferiu significativamente das heterozigosidades esperadas para A. amazonica e A. festiva (0,042 e 0,039 , respectivamente). Este resultado foi discutido como uma consequiência de hibridização entre duas subespécies geográficas de A. aestiva e, alternativamente, como uma característica particular da espécie. Comparada a aves em geral, a variabilidade genética de $A$. aestiva não é baixa, apesar deste papagaio ser uma das espécies mais comercializadas ilegalmente. A análise alozímica demonstrou ser uma ferramenta útil para o monitoramento da variabilidade genética do gênero Amazona, podendo ser aplicada em programas de manejo destas e de outras espécies ameaçadas pertencentes ao mesmo gênero.

Palavras-chave: variação genética, papagaios, alozimas, comércio ilegal.

\section{Introduction}

The risk of extinction is not randomly distributed across bird families. The Order Psittaciformes, for example, contains significantly more threatened species than would be expected by chance (Bennett and Owens, 1997). In the Neotropical parrots group, 31 percent of the 145 species are at global risk of extinction (Collar et al., 1994). According to the IUCN Red List of Threatened Fauna, among the 33 species of the genus Amazona dis- tributed worldwide, three are extinct, three are endangered, 11 are listed as vulnerable, and one is critically endangered (IUCN, 2006). In Brazil, three species of the genus Amazona are classified as vulnerable (Amazona brasiliensis Mercet, 1926, Amazona pretei Temminck, 1830 and Amazona vinacea Kuhl, 1820), and one is classified as endangered (Amazona rhodocorytha Salvadori, 1890). The species chosen for this study, Blue-fronted 
Amazon (Amazona aestiva Linnaeus, 1758), Orangewinged Amazon (Amazona amazonica Linnaeus, 1766, and Festive Amazon (Amazona festiva Linnaeus, 1758), were evaluated as "Least Concern" by Birdlife International IUCN (2006), and they are classified as "Appendix II" species on the Convention on International Trade in Endangered Species of Wild Fauna and Flora, which denotes their vulnerability due to illegal traffic (CITES Trade Database, 2005).

Although habitat destruction and small clutch sizes may contribute to the reduction of Neotropical parrot populations, the poaching of nestlings is the major cause of their decline (Wright et al., 2001). Poaching parrots is an economic activity driven by the demand of illegal pet trade. Wright et al. (2001) reported average US prices of US\$ 575.00 for Orange-winged Amazon, US\$ 711.00 for Blue-Fronted Amazon, and US\$ 2,150.00 for Festive Amazon. The Blue-fronted Amazon has been the more frequently negotiated species; it is estimated that between 1982 and 1986, approximately 51,000 specimens were exported to Argentina (Beissinger and Bucher, 1992). This exceeds the total number of individuals of all Amazon species exported to all other countries and, due to the relatively small population of the Blue-fronted Amazon in Argentina, Sick (1997) supposed that most of these parrots were captured in Brazil.

Brazilian zoos have maintained collections of many wild-caught Amazon parrots and most of these birds were sent to the zoos after the dealers were intercepted by the environmental police or by the Brazilian Environment Institute - IBAMA (Instituto Brasileiro do Meio Ambiente). Usually, birds are sent to zoos located near the area where the trade interception occurred.

Most studies on Amazon parrots are restricted to morphological, ecological, reproductive, or ethological aspects (Valentine, 1990; Marsden et al., 2000; Wright and Wilkinson, 2001; Ragusa-Neto, 2005; Raso et al., 2006; Sanz and Rodriguez-Ferraro, 2006; Fox and Millam, 2007). Genetic studies have focused on phylogenies (Eberhardt et al., 2001), and a broader phylogenetic study demonstrated that the group is not monophyletic (Russello and Amato, 2004).

However, studies on the genetic variability of Brazilian parrots of the genus Amazona are scarce. Wanjtal et al. (1995) evaluated the genetic variation of Brazilian zoo samples of four Amazona species using DNA fingerprint. They demonstrated that the two subspecies of the Blue-fronted Amazon differed in levels of variability - A. a. aestiva (Linnaeus, 1758) was more variable than A. a. xanthopteryx (Berlepsch, 1896) - and these two races were more variable than the Orangewinged Amazon. Recently, Faria and Miyaki (2006) found no genetic variation in zoo and wild samples of two species of the Amazona genus (A. pretrei and A. brasiliensis) using heterologous probes of single locus minisatellites, ten pairs of heterologous microsatellite primers (8 from domestic chicken, Gallus gallus, and 2 from hyacinth macaw, Anodorhynchus hyacinthinus
Latham, 1720 and seven tetranucleotide repeat primers to amplify inter-simple sequence repeats (ISSRs).

Genetic variation of wild-caught captive individuals of three Amazon parrots species was assessed in this paper using protein electrophoresis. We assumed that since the analyzed individuals were wild-caught, their genetic variability reflects the gene variation level of the wild populations. Additionally, we discussed allozyme analysis as a useful tool for investigating the genetic variation of other Amazon parrot populations that require more efforts for conservation purposes.

\section{Material and Methods}

\subsection{Sample collection}

We analyzed 68 wild-caught unrelated individuals belonging to three species sampled in three Brazilian zoos: the Blue-fronted Amazon, A. aestiva $(\mathrm{n}=25$; 7 from the Cuiabá zoo, Cuiabá, Mato Grosso State, and 18 from the São Carlos zoo, São Carlos, São Paulo State); the Orange-winged Amazon, A. amazonica $(\mathrm{n}=18 ; 6$ from the Manaus zoo, Manaus, Amazonas State, and 12 from the São Carlos zoo, São Carlos, São Paulo State), and the Festive Amazon, A. festiva ( $\mathrm{n}=25$, from Manaus, Manaus, Amazonas State). Parrots sampled at the Cuiabá zoo belong to the Pantanal region, and parrots from the Manaus zoo were captured in the Amazonian region. Parrots from the São Carlos zoo were mostly sent by IBAMA, and their probable origin is the central-western region of Brazil, including the Pantanal region.

Two geographic races of the Blue-fronted Amazon are distributed in South America: A. a. aestiva is observed in the eastern region and $A$. a. xanthopteryx in the western region, with an overlap area in the Pantanal region (Sick, 1997). Morphologically, these subspecies are differentiated by plumage color on the bend of the wing that is yellow in A. a. xanthopteryx and red in $A$. a. aestiva.

Blood samples $(0.2 \mathrm{~mL})$ were collected from each bird using EDTA as the anticoagulant. Each sample was centrifuged and separated into plasma and cells. Plasma was suctioned and cell fractions were frozen separately at $-20{ }^{\circ} \mathrm{C}$ for allozyme analysis.

\subsection{Protein electrophoresis}

Horizontal starch gel electrophoresis was carried out to study enzymes coded by ten presumptive genetic loci. Different buffers were used to achieve better resolution of the electrophoretic patterns of the following enzymes: acid phosphatase (Acp), EC 3.1.3.2 (tris-EDTA-maleate- $\mathrm{MgCl}_{2}, \mathrm{pH} 7.4$ buffer, TM); esterase (Est-D and Est- $\alpha-N A)$, EC 3.1.1.1 (TM); glucosephosphate isomerase (Gpi), EC 5.3.1.9 (tris-citrate, $\mathrm{pH} 8.0$ buffer, TC); glyoxalase I (Glo), EC 4.4.1.5 (TC); lactate dehydrogenase $(L d h)$, EC 1.1.1.27 (discontinuous histidinecitrate, pH 7.0-6.7 buffer, HC); peptidase A (Pep A), EC 3.4.11 (TC); phosphoglucomutase (Pgm), EC 5.4.2.2 (TM); 6-phosphogluconate dehydrogenase (6-Pgd), 
EC 1.1.1.44 (HC), and superoxide dismutase (Sod), EC 1.15.1.1 (TM). Reaction mixtures for the detection of enzyme activity were prepared following procedures described by Harris and Hopkinson (1976).

Electromorphs were assumed to be products of different alleles. Alleles were designated alphabetically in order of relative mobility from anode to cathode, with " $C$ " indicating the most common allele, and "B" and " $\mathrm{D}$ " representing more anodal or cathodal forms relative to "C", respectively. For Gpi phenotypes in the Festive Amazon population, " $F$ " was classified as the most common and "E" was classified as the more anodal form.

\subsection{Data analysis}

Allele frequencies were obtained through direct count. The proportion of polymorphic loci (\%), number of alleles per locus, and observed and expected underequilibrium heterozygosities were estimated using the
BIOSYS-1 program (Swofford and Selander, 1981), and were compared by chi-square $\left(\chi^{2}\right)$ values in a table with the absolute numbers of homozygotes and heterozygotes.

\section{Results}

Of the 10 analyzed gene loci, eight were polymorphic, with a mean number of alleles per locus ranging from 1.4 to 1.7 (Tables 1 and 2). Six rare alleles (frequencies lower than $5 \%$ ) were identified in the Bluefronted Amazon, three were identified in the Orangewinged Amazon, and four were identified in the Festive Amazon. Private alleles characterized these species: $G p i$ B, Glo B, Pgm D and Pep-A B alleles were restricted to the Blue-fronted Amazon, 6-Pgd B and D alleles occurred only in the Orange-winged Amazon, and Acp D and Est- $\alpha N A$ B alleles were observed only in the Festive

Table 1. Allele frequencies at ten allozyme loci in three species of Amazon parrots and chi-square $\left(\chi^{2}\right)$ values under assumption of the Hardy-Weinberg equilibrium (HWE).

\begin{tabular}{|c|c|c|c|c|c|c|}
\hline \multirow[t]{2}{*}{ Loci } & \multicolumn{2}{|c|}{$\begin{array}{l}\text { Blue-fronted Amazon } \\
\qquad(\mathbf{n}=\mathbf{2 5})\end{array}$} & \multicolumn{2}{|c|}{$\begin{array}{l}\text { Orange-winged Amazon } \\
\quad(\mathrm{n}=18)\end{array}$} & \multicolumn{2}{|c|}{$\begin{array}{l}\text { Festive Amazon } \\
\quad(n=25)\end{array}$} \\
\hline & Alleles & $\chi^{2}$ & Alleles & $\chi^{2}$ & Alleles & $\chi^{2}$ \\
\hline Acp & $\mathrm{C}(1.000)$ & & C (1.000) & & $\begin{array}{l}\mathrm{C}(0.980 \pm 0.022) \\
\mathrm{D}(0.020 \pm 0.022)\end{array}$ & 0.022 \\
\hline Est- $\alpha$-NA & $\mathrm{C}(1.000)$ & & $\mathrm{C}(1.000)$ & & $\begin{array}{l}\mathrm{B}(0.080 \pm 0.040) \\
\mathrm{C}(0.920 \pm 0.040)\end{array}$ & 0.057 \\
\hline Est-D & $\begin{array}{l}\text { B }(0.040 \pm 0.003) \\
C(0.940 \pm 0.003) \\
\text { D }(0.020 \pm 0.003)\end{array}$ & 0.420 & $\begin{array}{l}\mathrm{B}(0.050 \pm 0.006) \\
\mathrm{C}(0.950 \pm 0.006)\end{array}$ & 0.130 & $\begin{array}{l}\mathrm{C}(0.958 \pm 0.028) \\
\mathrm{D}(0.042 \pm 0.028)\end{array}$ & 0.167 \\
\hline Gpi & $\begin{array}{l}\text { B }(0.040 \pm 0.028) \\
C(0.960 \pm 0.028)\end{array}$ & 0.040 & C (1.000) & & $\begin{array}{l}\mathrm{E}(0.020 \pm 0.022) \\
\mathrm{F}(0.980 \pm 0.022)\end{array}$ & 0.022 \\
\hline Glo & $\begin{array}{l}\text { B }(0.040 \pm 0.028) \\
C(0.960 \pm 0.028)\end{array}$ & 0.070 & C (1.000) & & C (1.000) & \\
\hline Ldh & $\mathrm{C}(1.000)$ & & $\mathrm{C}(1.000)$ & & $\mathrm{C}(1.000)$ & \\
\hline Pep A & $\begin{array}{l}\text { B }(0.020 \pm 0.030) \\
C(0.980 \pm 0.030)\end{array}$ & 0.220 & C (1.000) & & $\mathrm{C}(1.000)$ & \\
\hline Pgm & $\begin{array}{l}\text { B }(0.120 \pm 0.010) \\
\text { C }(0.840 \pm 0.010) \\
\text { D }(0.040 \pm 0.010)\end{array}$ & 0.144 & $\begin{array}{l}\text { B }(0.111 \pm 0.040) \\
\text { C }(0.889 \pm 0.040)\end{array}$ & 0.110 & $\begin{array}{l}\mathrm{B}(0.020 \pm 0.022) \\
\mathrm{C}(0.980 \pm 0.022)\end{array}$ & 0.022 \\
\hline 6-Pgd & C (1.000) & & $\begin{array}{l}\text { B }(0.028 \pm 0.003) \\
\text { C }(0.944 \pm 0.003) \\
\text { D }(0.028 \pm 0.003)\end{array}$ & 0.420 & $\mathrm{C}(1.000)$ & \\
\hline Sod & $\mathrm{C}(1.000)$ & & $\mathrm{C}(1.000)$ & & $\mathrm{C}(1.000)$ & \\
\hline
\end{tabular}

Table 2. Genetic variability at 10 allozyme loci in three Amazon parrot species.

\begin{tabular}{|c|c|c|c|c|}
\hline \multirow[t]{2}{*}{ Amazon parrot } & \multirow{2}{*}{$\begin{array}{l}\text { Average number of alleles per } \\
\text { locus (standard error) }\end{array}$} & \multirow{2}{*}{$\begin{array}{c}\text { Percent } \\
\text { polymorphic loci }^{\mathrm{a}}\end{array}$} & \multicolumn{2}{|c|}{ Average Heterozygosity } \\
\hline & & & Observed & Expected $_{\mathrm{HWE}}$ \\
\hline Blue-fronted & $1.7(0.3)$ & 30 & $0.064 \pm 0.032$ & $0.060 \pm 0.028$ \\
\hline Orange-winged & $1.4(0.2)$ & 50 & $0.044 \pm 0.025$ & $0.042 \pm 0.023$ \\
\hline Festive & $1.5(0.2)$ & 50 & $0.032 \pm 0.013$ & $0.039 \pm 0.017$ \\
\hline
\end{tabular}

${ }^{\mathrm{a}} 0.95$ criterion. 
Amazon. Additionally, the alleles E and F observed at Gpi distinguished the Festive Amazon pattern from the other two species. Among all studied loci, Gpi and 6-Pgd seemed to be good diagnostic markers. The $\chi^{2}$ tests carried out for the different loci in the three samples showed no deviations from equilibrium.

The proportion of polymorphic loci ranged from 30 to 50 percent under a 95 percent criterion (Table 2). The percentage of polymorphic loci and the mean number of alleles per locus did not differ significantly between species. Blue-fronted Amazon average heterozygosity differed significantly from that of the Orange-winged Amazon and Festive Amazon $\left(\chi^{2}=4.33, \mathrm{p}<0.05\right)$.

\section{Discussion}

The average heterozygosity observed in the Bluefronted Amazon species (0.060) is close to the average value reported by Ward et al. (1992) in a review study including 172 avian species (0.068). Orange-winged Amazon and Festive Amazon, on the other hand, exhibited lower values (0.044 and 0.032, respectively). Although the lowest level of variability found in Festive Amazon is expected since it has the smallest distribution area of the three studied species (Infonatura, 2004), the variability level observed in Orange-winged Amazon can not be explained based on its geographic distribution. The number of rare and private alleles was also significantly higher for the Blue-fronted Amazon when compared to the other analyzed species.

Our first hypothesis to explain the higher variation level found in the Blue-fronted Amazon is that part of our sample could have a hybrid subspecies composition, although morphological analysis of the sampled parrots assigned them to the A. a aestiva subspecies. The two A. aestiva subspecies showed a significant differentiation level when evaluated through DNA fingerprinting patterns (Wanjtal et al., 1995). Bird hybridization is widespread - near one in ten species is known to hybridize and the true global incidence is likely to be much higher (Grant and Grant, 1992) - and allozyme loci are powerful genetic markers for revealing hybridization or introgression events involving species and subspecies (Frankham et al., 2002). However, only a further analysis including populations from areas where each subspecies occurs alone, and in the potential hybrid zones could test our assumption.

Alternatively, the higher level of variability detected in Blue-fronted Amazon could be a particular trait of this species. This proposition is in agreement with DNA fingerprinting data that also pointed Blue-fronted Amazon as more variable than the Orange-winged Amazon (Wanjtal et al., 1995), and with the high variability reported for an intraspecific chromosomal polymorphism associated to a broad interstitial band of heterochromatin within chromosome VI (Valentine, 1990).

Data revealing the extension of the illegal trade of the Blue-fronted Amazon parrots in Brazil point that, during a twelve-year period, the Center of Wild Animal Rehabilitation (CRAS) received over 2,500 nestlings il- legally transported across the state of Mato Grosso do Sul (Seixas and Mourão, 2000, 2002). Accurate statistics on the number of wild birds in illegal trade is not available and the number of birds removed from wild environments may be two to four times higher than that suggested by published data (Pain et al., 2006). Our results showed that, despite the intense persecution, Bluefronted Amazon genetic variability is comparable to that observed in non-traded species. However, as this species presents a long generation time, it is possible that the consequences of its decrease in population size will be detected only in the future, when species could be genetically impoverished.

Biodiversity is composed of ecological and genetic variation, and its evaluation is an essential step towards planning conservation strategies for endangered or vulnerable species (Schwartz et al., 2006). Birds are known to have lower gene variation when compared to other vertebrates (Ward et al., 1992). Considering only Amazon parrots studies, is noteworthy to observe the lack of genetic diversity reported by Faria and Miyaki (2006) on A. pretrei and A. brasiliensis analyses using highly polymorphic genetic markers. Although the vulnerable status of both species may explain the results, it shows how difficult is to find cross-species polymorphic genetic markers for population studies in this genus. The allozyme markers standardized here can be an alternative, fast, and easy approach toward evaluating the intraspecific and interspecific genetic diversity of these three Amazon parrot species as well as other vulnerable or endangered species that belong to sister groups. The application of these markers can also be useful to conservation follow-up programs, such as the successful reintroduction of captiveraised Yellow-shoulder Amazon parrots (A. barbadensis Gmelin, 1788) on Margarita Island in Venezuela (Sanz and Grajal, 1998), which is a model that can be proposed for vulnerable and endangered species in Brazil. Allozyme analysis has been increasingly replaced by DNA markers, but its use remains justifiable when it can contribute on additional information, mainly when rapid screening is required for a species from one genus and when hybridization is one of the hypotheses to be tested.

Acknowledgments - We gratefully acknowledge the technical support provided by IC. de Godoy and the assistance of JB. Pinho, D. Campista, and A. Kluczokovski for samples collection. We also acknowledge the useful suggestions made by two anonymous reviewers. FAPESP and CNPq provided financial support.

\section{References}

BEISSINGER, SR. and BUCHER, EH., 1992. Sustainable harvesting of parrots for conservation. In BEISSINGER, SR. and SNYDER, NER. (eds.). New World Parrots in Crisis: Solutions from Conservation Biology. Washington, Smithsonian Institution Press, p. 73-115.

BENNETT, PM. and OWENS, IPF., 1997. Variation in extinction risk among birds: chance or evolutionary predisposition? Proc. R. Soc. London B, vol. 264, no. 1380, p. 401-408. 
BIRDLIFE INTERNATIONAL, 2004. Amazona aestiva, Amazona amazonica, Amazona festiva. In IUCN 2007. 2007 IUCN red list of threatened species. www.iucnredlist.org. [Downloaded on 13 September 2007].

CITES - Convention on International Trade in Endangered Species of Wild Fauna and Flora, 2005. ww.cites.org. [Accessed: 18 August 2007].

COLLAR, NJ., CROSBY, MJ. and STATTERSFIELD, AJ., 1994. Birds to watch 2: the world list of threatened birds. Cambridge, Bird Life International, Conservation Series 4, 407p.

EBERHARD, JR., WRIGHT, TF. and BERMINGHAM, E., 2001. Duplication and concerted evolution of the mitochondrial control region in the Parrot Genus Amazona. Mol. Biol. Evol., vol. 18 , no. 7 , p. 1330-1342.

FARIA, PJ. and MIYAKI, CY., 2006. Molecular markers for populationgeneticanalysesinthefamilyPsittacidae(Psittaciformes, Aves). Genet. Mol. Biol., vol. 29, no. 2, p. 231-240.

FOX, R. and MILLAM, J., 2007. Novelty and individual differences influence neophobia in Orange-winged Amazon parrots (Amazona amazonica). Appl. Anim. Behav. Sci., vol. 104, no. $1-2$, p. $107-115$.

FRANKHAM R., BALLOU, JD. and BRISCOE, DA., 2002. Introduction to conservation genetics. Cambridge University Press, Cambridge, UK, 617p.

GRANT, PR. and GRANT, BR., 1992. Hybridization of bird species. Science, vol. 256, no. 5054, p. 193-197.

HARRIS, H. and HOPKINSON, DA., 1976. Handbook of enzyme electrophoresis in human genetics. Amsterdam, North Holland.

INFONATURA: Birds, mammals, and amphibians of Latin America [web application]. 2004. Version 4.1. Arlington, Virginia (USA): NatureServe. www.natureserve.org/infonatura. [Accessed: September 14, 2007].

IUCN - The World Conservation Union, 2006. Summary statistics for globally threatened species. www.iucnredlist.org/ search/search-basic. [Retrieved: May 5, 2006].

MARSDEN, SJ., WHIFFIN, M., SADGROVE, L. and GUIMARÃES, P., 2000. Parrot populations and habitat use in around two lowland Atlantic forest reserves, Brazil. Biol. Conserv., vol. 96, no. 2, p. 209-217.

PAIN, DJ., MARTINS, TLF., BOUSSEKEY, M., DIAZ, SH., DOWNS, CT., EKSTROM, JMM., GARNETT, S., GILARDI, JD., MCNIVEN, D., PRIMOT, P., ROUYS, S., SAOUMOÉ, M., SYMES, CT., TAMUNGANG, SA., THEUERKAUF, J., VILLAFUERTE, D., VERFAILLES, L., WIDMANN, P. and WIDMANN, ID. 2006. The impact of protection on nest-take and nesting success of parrots in Africa, Asia and Australasia. Anim. Conserv., vol. 9, no. 3, p. 332-330.

RAGUSA-NETTO, J., 2005. Extensive consumption of Tabebuia aurea (manso) Benth and Hook (Bignoniaceae) nectar by parrots in Tecoma savanna in the southern Pantanal (Brazil) Braz. J. Biol., vol. 65, no. 2, p. 339-344.

RASO, TF., SEIXAS, GHF., GUEDES, NMR. and PINTO, AA., 2006. Chlamydophila psittaci in free-living Blue-fronted
Amazon parrots (Amazona aestiva) and Hyacinth macaws (Anodorhynchus hyacinthinus) in the Pantanal of Mato Grosso do Sul, Brazil. Vet. Microbiol., vol. 117, no. 2-4, p. 235-241.

RUSSELLO, M., and AMATO, G., 2004. A molecular phylogeny of Amazona: implications for Neotropical parrot biogeography, taxonomy and conservation. Mol. Phylogen. Evol., vol. 30, no. 2, p. 421-437.

SANZ, V. and GRAJAL, A., 1998. Successful reintroduction of captive raised Yellow-shoulder Amazon parrots on Margarita Island, Venezuela. Conserv. Biol., vol. 12, no. 2, p. 430-441.

SANZ, V. and RODRIGUEZ-FERRARO, A., 2006. Reproductive parameters and productivity of the Yellowshouldered Parrot on Margarita Island, Venezuela: A long-term study. Condor, vol. 108, no. 1, p. 178-192.

SCHWARTZ, M., LUIKART, G. and WAPLES, RS., 2006. Genetic monitoring as a promising tool for conservation and management. Trends Ecol Evol, vol. 22, no. 1, p. 25-33.

SEIXAS, GHF. and MOURÃO, GM., 2000. Assessment of restocking Blue-fronted Amazon (Amazona aestiva) in the Pantanal of Brazil. Ararajuba, vol. 8, no. 2, p. 73-78.

SEIXAS, GHF. and MOURÃO, GM., 2002. Biologia reprodutiva do papagaio-verdadeiro (Amazona aestiva) no Pantanal sulmato-grossense, Brasil. In GALETTI, M. and PIZO, MA. (eds.). Ecologia e Conservação de Psitacídeos no Brasil. Belo Horizonte, Melopsittacus Publicações Científicas, p. 157-171.

SICK, H., 1997. Ordem Psittaciformes. In Ornitologia Brasileira. Rio de Janeiro, Brasil, Editora Nova Fronteira, p. 351-382.

SWOFFORD, DL. and SELANDER, RB., 1981. BIOSYS-1: a FORTRAN program for the comprehensive analysis of electrophoretic data in population genetics and systematics. $J$. Hered., vol. 72, no. 4, p. 281-283.

VALENTINE, M., 1990. Chromosome analysis. In STOODLEY, J., STOODLEY, P., EVANS, PGH., SCOTT, PW., VALENTINE, M., TEITLER, R. and HARRISON, GJ. (eds.). Genus Amazona. London, Bezels Publications, p. 127-131.

WANJTAL, A., MIYAKI, CY. and MENCK, CFM., 1995. Usando técnicas de DNA para preservar aves em extinção. Ciência Hoje, vol. 19, no. 1, p. 30-38.

WARD, RD., SKIBINSKI, DOF. and WOODWARK, M., 1992. Protein heterozygosity, protein structure and taxonomic differentiation. Evol. Biol., vol. 26, p. 73-159.

WRIGHT, TF. and WILKINSON, GS., 2001. Population genetic structure and vocal dialects in an Amazon parrot. Proc. R. Soc. London B, vol. 268, no. 1467 , p. 609-616.

WRIGHT, TF., TOFT, CA., ENKERLIN-HOEFLICH, E., GONZALEZ-ELIZONDO, J., ALBORNOZ, M., RODRIGUEZ-FERRARO, A., ROJAS-SUAREZ, F., SANZ, V., TRUJILLO, A., BEISSINGER, SR., BEROVIDES, AV., GALVEZ, XA., BRICE, AT., JOYNER, K., EBERHARD JR., GILARDI, J., KOENIG SE., STOLESON, S., MARTUSCELLI, P., MEYERS, JM., RENTON, K., RODRIGUEZ, AM., SOSAASANZA, AC., VILELLA, FJ., and WILEY, JW., 2001. Nest poaching in Neotropical parrots. Conserv. Biol., vol. 15, no. 3, p. $710-720$ 
